\title{
Local knowledge and perceptions of pet primates and wild Margarita capuchins on Isla de Margarita and Isla de Coche in Venezuela
}

\author{
Natalia Ceballos-Mago*, David J. Chivers \\ Wildlife Research Group, The Anatomy School, University of Cambridge, Downing Street, Cambridge CB2 3DY, UK
}

\begin{abstract}
Several primate species are currently threatened by the pet trade. Primate pet trade not only affects the animal that is kept in captivity, but is also a problem for wild primate populations already threatened by habitat destruction and fragmentation. Local knowledge and perceptions of pet primates and the wild Margarita capuchin Cebus apella margaritae were assessed through a pet survey on a regional scale, on Isla de Margarita and Isla de Coche in the state of Nueva Esparta in the Venezuelan Caribbean Sea. This assessment was conducted to generate recommendations for developing effective management strategies to stop the primate pet trade, for improving the welfare of these primates and for conservation of the Margarita capuchin. A semi-structured interview was used to gather information about species identification, age, husbandry methods, diet, behaviour, health and respondents' knowledge and perception, for a sample of 50 pet primates. The majority of pets were kept under inadequate conditions, without appropriate space, nutrition and veterinary assistance. Most respondents had no basic information about the existence and characteristics of the wild Margarita capuchin. Effective environmental education programmes in the study area should consider the current motivation of people acquiring primates as pets, in order to stop this practice and to incorporate local people into the conservation of the endemic Margarita capuchin.
\end{abstract}

KEY WORDS: Margarita capuchin - Pet trade - Cebus apella margaritae - Animal welfare • Isla de Margarita $\cdot$ Isla de Coche

\section{INTRODUCTION}

Challenges in conservation science include new approaches to understanding the human role in, and impact on, the environment and, in particular, on those species that have a close and historic relationship with humans through their use as game, domestic or experimental animals and pets (Fraser 1999, Bradshaw \& Bateson 2000, Chapman \& Peres 2001, Estrada 2009). Understanding human knowledge and perceptions of wild animal species can be a key factor in designing optimal and effective management strategies (Lamb \& Cline 2003, Priston 2005, Fuentes 2006, GarcíaLlorente et al. 2008).

The relationship between humans and other primates has varied historically and culturally. Human and non-human primates overlap in a complex array of circumstances that range from forest, to rural village to urban environments and from prey, to pets, to vectors of serious pathogens (Fuentes 2006). When kept as pets, primates act as surrogate infants, companions and/or entertainers (Fragaszy et al. 2004, Lee \& Priston 2005). The total number of pet primates worldwide is impossible to quantify, and trends in primate ownership have been difficult to estimate (Soulsbury et al. 2009). According to Eudey (1994) and Wright (2005), primate ownership has recently increased substantially in the range states. Fuentes (2006) stated that ownership of selected pet primates is currently widespread in South and Southeast Asia, in Africa and in South America, especially in Amazonia.

Several primate species are currently threatened by the pet trade, but detailed assessments of the trade in wild primates are still needed in order to mitigate the 
threat (Chapman \& Peres 2001, Nijman 2005, Estrada 2009). Primate trade affects the animal that is kept in captivity and is problematic for primate populations already threatened by poaching for meat or pest control, habitat destruction and fragmentation (Eudey 1994, Duarte-Quiroga \& Estrada 2003). Changing the perceptions of people towards the primate pet trade has proved to be difficult, and there is an urgent need for innovative approaches that can generate this change of mindset (Chapman \& Peres 2001, Nijman 2005).

There have been a few initiatives for researching the pet trade in the Neotropics, and they point to the need for more systematic and intensive surveys to understand the extent of the threat for wildlife populations and to find creative and effective conservation actions (Chapman \& Peres 2001, Duplaix 2001, DuarteQuiroga \& Estrada 2003, Kierulff et al. 2005, Altherr 2007, Estrada 2009). In Venezuela, although hunting of primates is illegal, the legislation regarding keeping any wildlife as a pet is insufficient (Mujica et al. 2003). A few non-governmental organisations (NGOs) have mounted local education campaigns to stop the pet trade, but they need support to broaden the message at the national level for long-term conservation purposes (Mujica et al. 2003, L. Alió pers. comm.).

For Venezuela, Ceballos-Mago et al. (2010) presented the national and international scale of the pet trade in the state of Nueva Esparta, the primate species involved in the trade, as well as the impact of this trade on the conservation of the Margarita capuchin Cebus apella margaritae. This capuchin is an endemic and Critically Endangered primate of Isla de Margarita in Nueva Esparta (Ceballos 2008). It is threatened because it lives in a reduced and fragmented habitat and also by poaching for pest control and the pet trade (Sanz \& Marquez 1994, Rodríguez \& Rojas-Suárez 1999, 2008, Ceballos 2008). In this study, using the same pet-primate population, we characterise the knowledge and perceptions of local people keeping primates as pets towards these primates and towards the wild Margarita capuchin, in order to generate recommendations for effective management strategies to stop the primate pet trade, for improving the welfare of these primates and for the conservation of the Margarita capuchin.

\section{MATERIALS AND METHODS}

Study area. This study was conducted at a regional scale on Isla de Margarita $\left(1071 \mathrm{~km}^{2}\right.$; 400000 inhabitants) and Isla de Coche $\left(55 \mathrm{~km}^{2} ; 12000\right.$ inhabitants $)$ in the state of Nueva Esparta in the Venezuelan Caribbean Sea (Fig. 1). Isla de Cubagua $\left(24 \mathrm{~km}^{2} ; 50\right.$ inhabitants), the third island that is part of this state, had no pet primates when the general survey was conducted (Ceballos-Mago et al. 2010).

The Margarita capuchin is the only wild primate in the state of Nueva Esparta. It is endemic to the largest island, Isla de Margarita (Fig. 1), which is located $23 \mathrm{~km}$ from the Venezuelan mainland (MARNR 1994) (further details about the distribution of the Margarita capuchin in Ceballos-Mago et al. 2010). This island is among the most diverse in the Caribbean, in terms of the number of species and ecosystems harboured (Rodríguez 2007a, Sanz 2007). Two national parks (NP) and 3 natural monuments (NM) have been declared on Margarita (NP: Cerro el Copey and Laguna de la Restinga, NM: Laguna de las Marites, Tetas de María Guevara and Cerros Matasiete Guayamurí). On Margarita, 31 mammals, 158 birds, 42 reptiles and 6 amphibians have been found (Bisbal 2008). Of these, 28 species (including sub-species) of terrestrial vertebrates have been reported as endemic, endangered or habitat specialists with restricted distribution on Isla de Margarita, for which the current protected areas are insufficient to guarantee their viability (Sanz 2007). At least 1 Critically Endangered species of mammal, Margarita deer Odocoileus virginianus margaritae, and 3 threatened subspecies, Margarita capuchin Cebus apella margaritae, rabbit Sylvilagus floridanus margaritae and squirrel Sciurus granatensis nesaeu, inhabit the mountains of the east side of the island (Rodríguez \& Rojas-Suarez 2008).

Isla de Margarita is an important tourist destination for Venezuelans, but it is also visited by foreigners, mainly Europeans (Sanz \& Marquez 1994, CORPOTUR 2009). Tourist development is focused in the eastern sector of Isla de Margarita, while Península de Macanao, in the west, is inhabited mainly by fishermen. The tourist business on Isla de Coche has also been growing recently.

Data collection and analysis. In this study, 'respondents' refers to a sample of the local people keeping primates as pets. From a total of 162 pet primates sampled in a general survey across the state of Nueva Esparta (Ceballos-Mago et al. 2010), an assessment of local perceptions and knowledge of pet primates and wild Margarita capuchins was carried out for a sample of 50 pets. The interviews were conducted in Spanish by N.C.M., accompanied on some occasions by assistants, between March 2005 and April 2008. All interviews were conducted directly in the locations where the pet primates were being kept (41 were in houses and 9 in restaurants or other commercial establishments). Completion of the 162 interviews was not possible, because at the first visit some people did not feel comfortable talking about the primates; they were afraid that the primate would be taken away. In other cases, people with all the information about the primate were not present or were difficult to find. After 


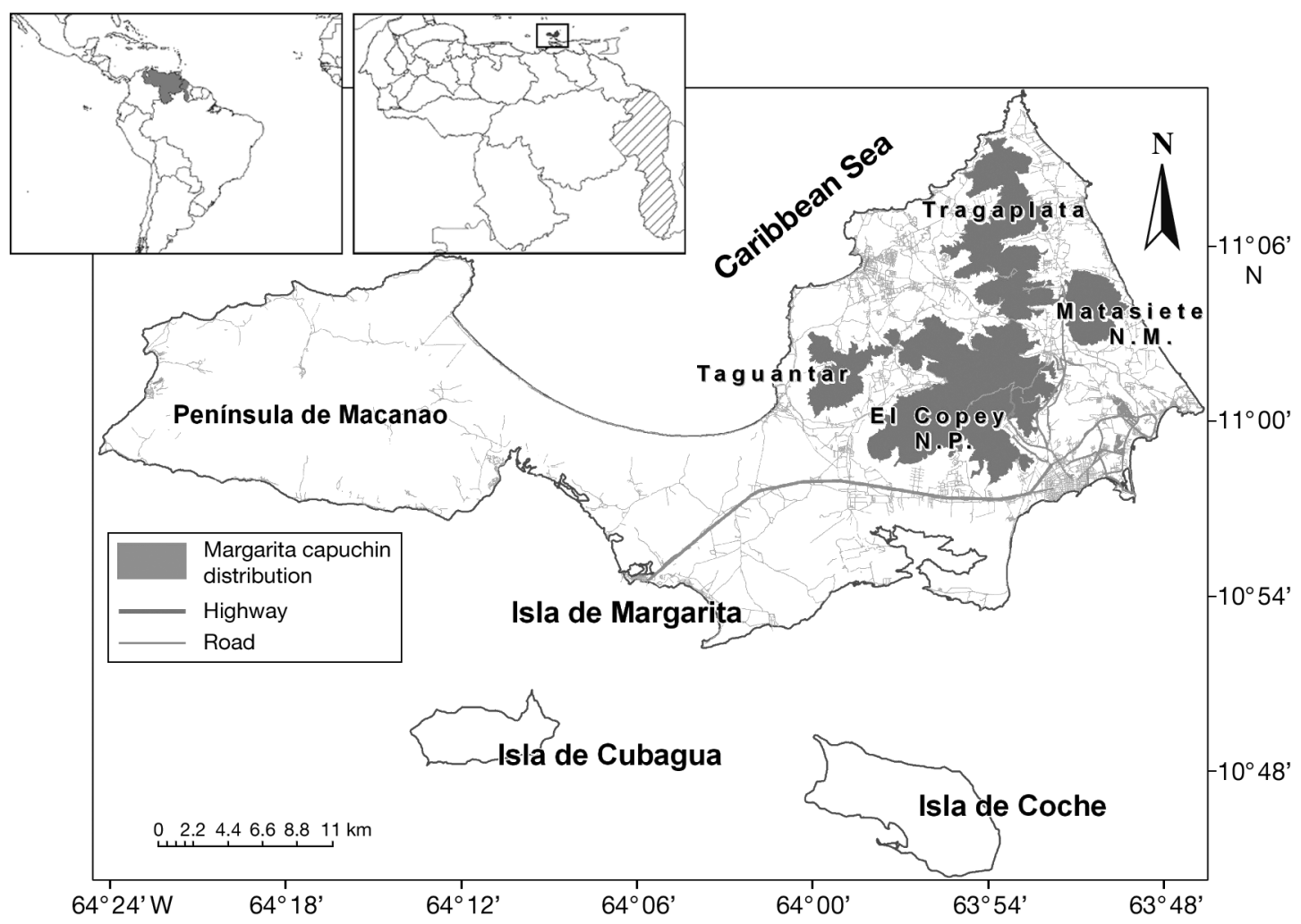

Fig. 1. Study area in Venezuela: Isla de Margarita and Isla de Coche. The distribution of the Margarita capuchins comprises 4 mountain forest fragments: Cerro El Copey National Park (7130 ha, 930 m a.s.l.), Cerro Matasiete (1145 ha, 66 m a.s.l.) which is part of Cerros Matasiete y Guayamurí Natural Monument, Tragaplata range (4000 ha, 680 m a.s.l) and Cerro Taguantar (1300 ha, $500 \mathrm{~m}$ a.s.l.). Valleys with towns, agricultural areas and roads separate these mountain forest fragments (Ceballos-Mago et al. 2010)

the second or third visit, people felt confident, being very friendly and willing to talk, but, due to the project schedule, it was not feasible to visit every location repeatedly to complete the interview, so only the basic information was gathered for all 162 pets found, and more detailed information for the sample of 50 .

After a preliminary survey conducted in 2005 (Ceballos-Mago 2005), we designed a semi-structured interview to gather information about general characteristics and husbandry of the pet primates as well as respondents' knowledge and perception. The following data were collected:

(1) General characteristics: primate species (identified by N.C.M.), sex and age of the primate estimated from information provided by the respondent.

(2) Husbandry: methods (we measured the cages, ropes and chains used to keep the pet primates), diet, health, behaviour and presence of other pets.

(3) Respondent's knowledge of primate-pet species and reasons for acquiring pet primates.

(4) Respondent's knowledge and perception of Margarita capuchin wild population.

Data from the pet survey were entered in a database (Excel). Open-ended questions were codified to facilitate analysis. Thus, for instance the respondents' knowledge of physical characteristics of the Margarita capuchin, as well as their estimations of the capuchins' abundance were classified in categories, and primate ages were classified into age classes: infant ( $\leq 6 \mathrm{mo})$, juvenile ( $7 \mathrm{mo}$ to 2 yr), sub-adult (3 to 5 yr), adult (> 5 yr) (Rowe 1996, Di Bitetti \& Janson 2001, Fragaszy et al. 2004). Descriptive statistics were conducted for the data collected.

\section{RESULTS}

\section{General characteristics of the pet primates}

Species

Wedge-capped capuchin Cebus olivaceus, Margarita capuchin, common squirrel monkey Saimiri sciureus, red howler monkey Alouatta seniculus and brown capuchin Cebus apella apella were the pet primates in the sample (Table 1). The majority were wedge-capped capuchin $(56 \%, \mathrm{n}=28)$, followed by the Margarita capuchin $(34 \%, \mathrm{n}=17$; Table 1$) ; 7$ were on Isla de Coche and 43 were on Isla de Margarita. 
Table 1. Number of individuals and percentage of each petprimate species or sub-species in a sample of 50 primates

\begin{tabular}{|llcc|}
\hline Common name & Scientific name & $\mathrm{N}$ & $\%$ \\
\hline $\begin{array}{l}\text { Wedge-capped } \\
\text { capuchin }\end{array}$ & Cebus olivaceus & 28 & 56 \\
Margarita capuchin & $\begin{array}{c}\text { Cebus apella } \\
\text { margaritae }\end{array}$ & 17 & 34 \\
$\begin{array}{l}\text { Common squirrel } \\
\text { monkey }\end{array}$ & Saimiri sciureus & 2 & 4 \\
Red howler monkey & $\begin{array}{l}\text { Alouatta seniculus } \\
\text { Brown capuchin }\end{array}$ & 2 & 4 \\
Total & Cebus apella apella & 1 & 2 \\
\hline
\end{tabular}

\section{Age}

All primates in this sample were received or purchased when they were infants or juveniles, which allowed us to estimate their age at the time of the interview. Sub-adult $(40 \%, \mathrm{n}=20)$ was the most abundant age class, followed by juveniles $(26 \%, \mathrm{n}=13)$ and adult $(26 \%, \mathrm{n}=13) ; 8 \%(\mathrm{n}=4)$ were infants. The oldest animal was about 20 yr old, and $74 \%(n=37)$ of pet primates were $\leq 5 \mathrm{yr}$ old.

\section{Sex}

Sex of primates could not be determined in most cases. It was not always possible to check sex during the survey, because not all respondents were willing to manipulate their pet, so we excluded these data for analysis. When it was possible to check sex, many mistakes were found, as many females are identified as males due to similarities when young.

\section{Husbandry}

Methods

The most common method used to keep primates was to tie their waist with a short rope or chain (mean length $=2 \mathrm{~m}$ ), attached to a tree or a column of the house $(64 \%, n=32)$. A small cage (mean volume $\left.=1 \mathrm{~m}^{3}\right)$ was the other method used (36\%, $\mathrm{n}=18$; Fig. 2). Most respondents $(94 \%, \mathrm{n}=30)$ refused to lengthen the rope or chain, because of concerns regarding aggression to children and visitors $(67 \%, \mathrm{n}=20)$, as well as for protection of their property $(13 \%, \mathrm{n}=4)$ or because they thought the primate was in good condition $(20 \%, n=6)$. For primates kept in cages, most respondents $(78 \%, \mathrm{n}=$ 14) refused to build a larger cage. Reasons given were concerns regarding aggression to children and visitors

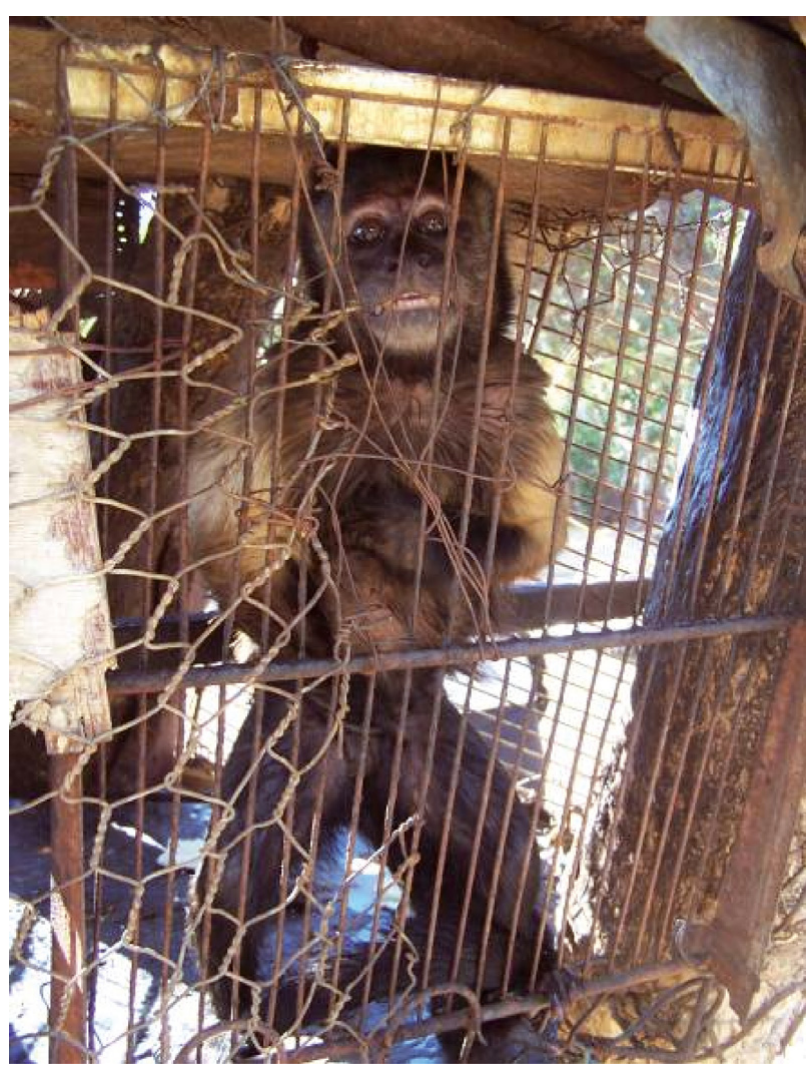

Fig. 2. Cebus apella margaritae. Pet Margarita capuchin in a very small cage

$(50 \%, \mathrm{n}=7)$, because they thought the primate was in good condition $(36 \%, \mathrm{n}=5)$, or because of lack of money $(14 \%, n=2)$. Only a few respondents $(n=6)$ planned future improvements for the method used to keep the pets.

\section{Diet}

Most respondents (96\%) fed the primates with the same food as they consumed themselves, given the local belief that 'monkeys eat everything'. Fish, chicken, meat, beans, arepas (corn bread), coffee, rice and fruits were the most common foods eaten by people and given to the pet primates. Only $4 \%$ of the respondents considered the special requirements of a primate's diet. Neotropical primates are mainly frugivorous (see 'Discussion' for more details).

\section{Health conditions}

The majority of pet primates had not received any veterinary assistance $(66 \%, n=33)$, and $32 \%(n=16)$ had suffered health problems. Stomach problems were 
the most common reported; eye sickness, abscesses, flu, fever, dehydration, respiratory conditions, mycotic dermatitis, paraplegia and bone fractures were also reported by respondents.

At the end of the study, at least 5 of the total 50 pet primates surveyed had died. Three of these were Margarita capuchins, 1 of whom died from eating a poisonous plant. For other primates not included in the sample, local people and veterinarians reported the following causes of death: peritonitis, kidney tumour, wasp attack, strangulation (collar too tight), malnutrition, intra-specific killing, parasitic infection and human-caused death after the pet primate escaped (the primate was shot after neighbours complained of a stray primate destroying their property).

\section{Pet-primate behaviour}

Aggressive behaviour by primates was reported by the respondents. Half of the primates in the sample $(\mathrm{n}=$ 25) had bitten someone at least once, causing small to very serious injuries. Not only sub-adult and adult individuals, but also juveniles showed aggressive behaviours, according to respondents. Some respondents $(6 \%, n=3)$ attempted to suppress the effect of this aggressive behaviour by removing the canines (tusks) either by themselves or with veterinary assistance.

Predation of insects and domestic animals was also considered by respondents as an aggressive and abnormal behaviour. Pet squirrel monkeys and capuchins in the study were reported to catch insects. Capuchins were also reported to catch chickens to eat them or to pluck them without eating them. Primates were punished after these events.

\section{Other pets}

In $98 \%(n=49)$ of the cases, there were other animals living in the same place as the primates, including dogs, cats, pigs, ducks, parrots, goats, redfooted tortoises, Margarita rabbits and squirrels, toucans, ornamental birds and chickens.

\section{Respondents' knowledge and motivations}

In $56 \%(n=28)$ of cases, respondents did not know the common name of the primate species they housed; $78 \%$ ( $\mathrm{n}=$ 39) had no information about primate lifespan, while $10 \%(\mathrm{n}=5)$ estimated $40 \mathrm{yr}, 8 \%(\mathrm{n}=4)$ estimated $>40 \mathrm{yr}$ and $4 \%(\mathrm{n}=2)$ up to $15 \mathrm{yr}$.

The most common reason for acquiring a pet primate was that a member of the family liked primates $(44 \%, n$ =22); other reasons included receiving the primate as a present $(20 \%, \mathrm{n}=10)$, concern for the animal's welfare $(16 \%, \mathrm{n}=8)$, for company $(4 \%, \mathrm{n}=2)$, to attract customers $(4 \%, \mathrm{n}=2)$, company for an existing primate $(4 \%, n=2)$, the primate arrived by itself, close to the house and was captured $(4 \%, n=2)$ and to sell for extra income ( $4 \%, n=2 ;$ Fig. 3$)$. Since hunting of and/or selling primates is illegal in Venezuela, this is a clandestine trade. Primates were bought at an average price \pm SE of US\$ $169.30 \pm 59.60$ (Ceballos-Mago et al. 2010).

Although only 2 respondents expressed that their motivation to keep a pet primate was to attract customers, 8 primates in the sample of 50, and 38 among the 162 total pet primates found (Ceballos-Mago et al. 2010), were exhibited in restaurants or other commercial establishments owned by the respondents.

\section{Respondents' knowledge and perceptions of wild Margarita capuchins}

Only $16 \%(\mathrm{n}=8)$ of the respondents knew that there was only 1 wild primate species on Isla de Margarita, $66 \%$ (n = 33) did not know how many wild primate species live on the island, and $18 \%(\mathrm{n}=9)$ thought there was more than 1 species.

Most respondents could not describe a Margarita capuchin $(62 \%, \mathrm{n}=31), 34 \%(\mathrm{n}=17)$ described it close to its dark colour, while the characteristics mentioned by $4 \%(n=2)$ did not correspond to this taxon.

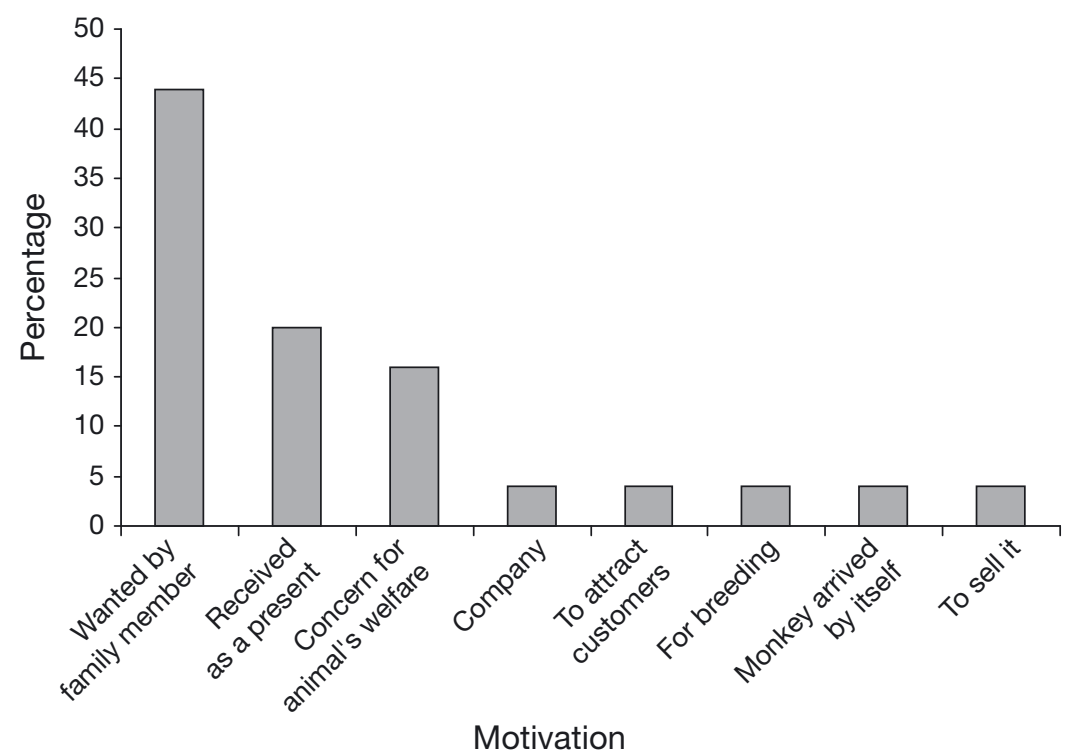

Fig. 3. Reasons for aquiring pet primates 
In general, respondents exhibited restricted knowledge regarding the Margarita capuchin. Half of the respondents $(\mathrm{n}=25$ ) had no information about its abundance in the wild, $30 \%(n=15)$ thought that this species was abundant, and $20 \%(\mathrm{n}=10)$ thought that only a few primates inhabit the mountains (no figures were estimated).

The species distribution was unknown by $38 \%$ ( $\mathrm{n}=$ 19) of respondents, $12 \%(n=6)$ described it as being distributed across all mountains on the island, including the ones in the west (Península de Macanao), and $50 \%$ ( $\mathrm{n}=25)$ mentioned only specific mountains or areas close to where they live. Most respondents $(7$ of 10 ) in the communities of the west sector of Isla de Margarita (Península de Macanao) and on the small island Isla de Coche (6 of 7 respondents) had no information about the presence of an endemic primate on Isla de Margarita.

\section{DISCUSSION}

\section{General characteristics of pet primates and husbandry}

Species and age

All pet primates found were Neotropical species. They were all native species, but the common squirrel monkey and the brown capuchin surveyed came to the islands through the international trade from the Guyana Shield ecoregion (Ceballos-Mago et al. 2010). The wedge-capped capuchin and Margarita capuchin were the most common pets in the sample. The wedgecapped capuchin is widely distributed in Venezuela and is listed as one of the species most threatened by illegal trade in the country (Mujica et al. 2003). Capuchins in general have been commonly kept as pets in their countries of origin as well as in the United States and Europe, and they have been shown in many movies as the 'typical' monkey (Cormier 2002, Fragaszy et al. 2004, Soulsbury et al. 2009). In the present study, sub-adult was the most abundant age class, but all primates were received or purchased when they were infants or juveniles, which is the age when primates make appealing pets (Duarte-Quiroga \& Estrada 2003, Wright 2005, Cheyne 2009, Nijman 2009).

\section{Husbandry}

As for any other wild species, primates have specific physiological, physical, psychological, social and nutritional requirements that are impossible to fulfil when they are kept as pets (Hevesi 2005). The lack of basic knowledge about the ecology, behaviour and requirements of the wild species kept as pets directly affects pet-primate welfare (Duarte-Quiroga \& Estrada 2003). Using the framework of Schuppli \& Fraser (2000), Soulsbury et al. (2009) proposed to assess pet-primate welfare based on tangible issues, such as diet, environmental housing, social interaction and behaviour. Using their approach, we consider that pet husbandry on the islands surveyed is far from adequate and that there is a lack of appropriate welfare conditions.

The most common method used to keep primates on Isla de Margarita and Isla de Coche was to tie their waist with a short rope or chain attached to a tree or a column of the house. Keeping primates tied up has also been reported in other studies (Duarte-Quiroga \& Estrada 2003, Wright 2005). Cage size observed in our study was too small, allowing very limited movement for the pets. To ensure good welfare, it is necessary to provide good housing of adequate size and quality, with conditions and facilities not normally found in private households, such as appropriate temperature, humidity, light and opportunity to express speciestypical behaviours (Prescott \& Buchanan-Smith 2004, Fragaszy 2005, Hevesi 2005).

Diet requirements were not fulfilled for primate pets in our study. Neotropical primates are mainly frugivorous (Terborgh \& van Schaik 1987, Kappeler \& Heymann 1996). There are some differences in diet requirements among the species kept as pets in this study. Capuchins are primarily frugivorous, but insects are an important part of their diet, and they have also been reported to consume vertebrates, such as birds and their eggs, lizards, frogs, rodents, bats, squirrels and coati pups (Chapman 1988, Fragaszy et al. 2004). Howler monkeys are mainly considered folivorous, but fruit is also an important component of their diet (Julliot 1996), and squirrel monkeys are primarily insectivorous, but fruit is also very important in their diets (Lima \& Ferrari 2003). In our study, these requirements were not considered by most respondents. The primates in the sample were fed with the same food as that consumed by people. Since primate health is linked to diet, an inappropriate diet can increase susceptibility to disease (Soulsbury et al. 2009). The digestive problems reported by respondents as the most common problem of their pet primate could be related to an inappropriate diet. The lack of knowledge about diet of primates also led to primates being punished for eating insects and domestic animals because respondents interpreted these behaviours as abnormal. Duarte-Quiroga \& Estrada (2003) also found that pet primates in Mexico City did not have an adequate diet; they were fed with the same food that people ate and also ingested substances, such as alcohol, paper, tobacco and marijuana that could affect their health. 
Lack of veterinary care for pets can result in diseases that are not detected and treated. Pet primates also pose a risk to human health and safety, in terms of direct physical injuries as well as disease transmission. Since human and non-human primates often share diseases when they come into physical contact, the risk of disease transmission increases (Renquist 1987, JonesEngel et al. 2004). The pet trade facilitates zoonoses (primate diseases transmissible to humans), that can potentially cause public epidemics and anthropozoonoses (diseases that humans may transmit to nonhuman primates; Chapman et al. 2005, Corning 2005). The digestive problems reported by respondents as the most common problem of their pet primates could also be related to a symptom of intestinal parasite infection that has been detected in pet primates on the islands (Ceballos-Mago et al. 2010). For future research projects, we have already planned a health evaluation of the pet primates and identification of these pets by microchip or other means, in collaboration with a multi-disciplinary team in Venezuela.

The frequent presence of other domestic and wild animals in close proximity to the primates can contribute to the transmission of intestinal parasite infection. The interaction of pet primates with some of these other animal species can also cause distress, as well as neurotic and fearful behaviour in the primate (Hevesi 2005). The absence of other primates to develop the normal social interactions can also affect pet behaviour (Johnson-Delaney 1991).

\section{Respondents' knowledge about primate-pet species and motivations to acquire pet primates}

Only a small percentage of respondents were aware that primates can live up to 20 to $40 \mathrm{yr}$. Welfare of pets should be guaranteed for the individual's entire life span, which requires interest and commitment for a long period, particularly in the case of primates as longlived animals (Renquist 1987, Soulsbury et al. 2009).

The most common reason for acquiring a pet primate in this study was that a member of the family liked primates. This is similar to the main motivation for respondents in Mexico City who owned a pet for empathy (Duarte-Quiroga \& Estrada 2003). The conflict between farmers and crop-raiding macaques was identified in Buton, Indonesia, as the main reason for the acquisition of primates to be kept as pets (Wright 2005).

Primates are very active and require a stimulating environment (Fragaszy 2005, Soulsbury et al. 2009). Only a few respondents perceived that the rope was too short or the cage too small and planned to improve them. The normal aggressive behaviour that primates display after reaching sexual maturity was interpreted as abnormal by respondents. Their welfare is diminished when such changes in behaviour occur, since this commonly leads to their isolation. Removal of the canines to suppress or mitigate the effect of primate bites is physically and psychologically damaging for the animal and does not solve the problem (Hevesi 2005). One of the causes of death among pet primates reported in Mexico City was the killing of the pet after an aggresive incident (Duarte-Quiroga \& Estrada 2003).

\section{Respondents' knowledge and perceptions of wild Margarita capuchins}

Knowledge of the distribution, abundance and description of the endemic Margarita capuchin was limited to a very small percentage of the interviewees, and these individuals only had very restricted information which related only to the capuchins living in sectors of the mountain close to their towns. This local perception of the fauna distribution was also expressed by hunters (N. Ceballos-Mago unpubl. data). Some interviewees expressed surprise when they were informed of the existence of an endemic primate on Isla de Margarita (N. Ceballos pers. obs.), while others thought that these primates inhabited every mountain of Isla de Margarita including the Península de Macanao, which is far from this capuchin's distribution. Since there are no regional environmental education programmes focussed on endemic and endangered species or ecosystems, knowledge of local people on the islands surveyed seems to come only from personal experience. This could explain the lack of knowledge about Margarita capuchins among the people interviewed on the Península de Macanao (west Isla de Margarita) and Isla de Coche, both of which are some distance from the distribution of Margarita capuchins.

Contact with the mountains is restricted to a small percentage of local people who practise hunting and agricultural activities in the east of Isla de Margarita. Agriculture was one of the main commercial activities before the 1970s when Isla de Margarita was declared a duty-free port and the rural economy shifted to intense touristic, commercial and service activities, specifically in the east of the island (Sanz 2007). Currently, this tendency persists in eastern Isla de Margarita and more recently has increased on Isla de Coche, while on Península de Macanao (west Isla de Margarita), the main source of employment is fishing.

\section{Conservation implications and recommendations}

Public knowledge affects the public's involvement in conservation activities and can influence government 
and NGO decision-making (Wilson \& Tisdell 2005). Acquiring primates as pets should be strongly discouraged. Although a person currently keeping a pet primate may be difficult to convince, a person considering such a pet could be dissuaded (Renquist 1987). Working with the communities through education programmes at different levels, including in schools, will be a key factor for stopping the pet trade and for the conservation of the Margarita capuchin. For animal welfare reasons, and to avoid reinforcing the existing motivation of having a primate pet at home, exhibition of any primate-pet species in restaurants and other commercial places must be banned.

On Isla de Margarita, several species are captured for the pet trade, but no systematic records exist, except for the yellow-shouldered Amazon Amazona barbadensis (J.M. Briceño pers. comm.), one of the most common pets on the island that has suffered seriously from the illegal extraction of individuals for the pet trade (Albornoz et al. 1994). The hunting pressure still persists for this species. According to the results from recent surveys, the number of parrots kept as pets is higher than the number of wild individuals (J.M. Briceño pers. comm.), but in an integrated conservation project located on the Península de Macanao, there has been success in increasing the wild population size, through several actions that have included biological research, population management, environmental education, participation and awareness of local human communities and strengthening protected-area management and design (Sanz \& Grajal 1998). This local education project on Península de Macanao focused on the yellow-shouldered parrot can be a model for future programmes focused on other endemic species (Sanz \& Grajal 1998, Rodríguez 2007b).

Due to the current lack of basic information about primates found in the sample of local people that kept primates as pets, future education programmes should include information about primate species, the potential for suffering of animals during capture and travelling to reach the islands and discussion of the implication of the pet trade in the conservation of wild primate populations, as well as the basic principles of animal welfare. Differences in perception and knowledge of local people across the communities must be considered when developing effective environmental education programmes. To accomplish this, we recommend conducting a survey that includes a broader representation of the communities to include not only local people who keep primates as pets, but also other members of the communities, and considering variables such as age and occupation of the respondents. Assessment of attitudes should also be included in the next survey.

Monkey Rescue Centres must be established on Isla de Margarita to manage the captive Margarita capuchin population for conservation purposes (Ceballos-Mago et al. 2010), and also on the Venezuelan mainland to receive the other primate species. These centres can follow and adapt to their own requirements both the advances made in this field in Latin America over the last $20 \mathrm{yr}$ (Lozada 2008) and the recommendations for keeping capuchins in captivity (Fragaszy 2005). Compared to other Latin American countries, Venezuela is behind in wildlife rehabilitation (Lozada 2008). ARFA (Asociación de Rescate de Fauna), the only rehabilitation centre legally authorised on the Venezuelan mainland, closed in 2007 (L. Alió pers. comm.). A wildlife rehabilitation centre in Nueva Esparta state, FUNDANISIL, was legally authorised in 2008, but they do not have capacity for all pet primates that are already in Nueva Esparta (S. Durandeau pers. comm.). Due to the current lack of sufficient rehabilitation centres, confiscated animals are sent to zoos or left in captivity in the same location, and temporary custody is given to the person who kept the primate (Lozada 2008).

The establishment of Rescue Centres specifically for primates would provide proper welfare for the pets in captivity and could run environmental education programmes to broaden public awareness. During the survey, some respondents were already willing to give up the primates voluntarily (N. Ceballos pers. obs.). Since the main motivation to keep pet primates was that someone in the house liked them, this motivation could be channelled to incorporate those people in voluntary work in the centre on Isla de Margarita.

The importance of the Margarita capuchin as the only wild primate of the region and the role of local communities to support conservation initiatives for this primate and its habitat must be emphasised. These communities can make valuable contributions to the promotion of the Margarita capuchin as an environmental educational flagship for local people and tourists. Experiences from other primate projects that incorporate the local communities at different levels, such as muriqui, golden-lion tamarin, yellow-breasted capuchin and black lion tamarin projects in Brazil and Proyecto Titi in Colombia (Kierulff et al. 2005, Savage et al. 2010) must be considered and adjusted to the reality on Isla de Margarita.

Acknowledgements. We thank C.E. González for the map, and S. García-Rangel, A. Pinto, V. Nijman, C. Besançon and 4 anonymous reviewers for valuable suggestions that helped to improve the manuscript. INPARQUES provided long-lasting support, and we especially thank A. Marcano and park rangers I. Valera, P. Marcano, M. Gil and D. Gomez for their participation in the pet survey. Fundacion Vuelta Larga and the Wildlife Research Group provided institutional support. V. Zacarías and A. Rodríguez also participated in the surveys. Thanks to M. Forti and L. Alio (ARFA) for bibliographic references and to J. Romero and the Perera-Morales and Ceballos- 
Mago families for logistic support. Financial support was provided by Captive Care Grant (IPS), Fondo IEA, Primate Action Fund (CI), Denver Zoological Foundation, Rufford Small Grant, IDEA WILD, Cambridge Overseas Trust, Cambridge Philosophical Society, The Anatomy School and Murray Edwards College (formerly New Hall).

\section{LITERATURE CITED}

Albornoz M, Rojas-Suarez F, Sanz V (1994) Conservación y manejo de la cotorra cabeciamarilla (Amazona barbadensis) en la Isla de Margarita, Estado Nueva Esparta. In: Morales G, Novo I, Bigio D, Luy A, Rojas-Suarez F (eds) Biología y conservación de los psitacidos de Venezuela. Gráficas Giavimar, Caracas, p 197-207

Altherr S (2007) Going to pot - the Neotropical bushmeat crisis and its impact on primate populations. Care for the Wild \& Pro Wildlife, Kingsfold, and Pro Wildlife, Munich

Bisbal F (2008) Los vertebrados terrestres de las Dependencias Federales de Venezuela. Interciencia 33:103-111

Bradshaw E, Bateson PPG (2000) Animal welfare and wildlife conservation. In: Gosling LM, Sutherland WJ (eds) Behaviour and conservation. Cambridge University Press, Cambridge, p 330-348

Ceballos N (2008) Cebus apella ssp. margaritae. In: 2008 IUCN Red List of Threatened Species. www.iucnredlist. org

Ceballos-Mago N (2005) Pet primates on Isla de Margarita, a threat for the wild population of the Margarita capuchin monkey (Cebus apella margaritae). VI Congreso Venezolano de Ecología, Maracaibo

Ceballos-Mago N, González CE, Chivers DJ (2010) Impact of the pet trade on the Margarita capuchin monkey Cebus apella margaritae. Endang Species Res 12:57-68

Chapman C (1988) Flexibility in diets of three species of Costa Rican primates. Folia Primatol (Basel) 49:90-105

- Chapman CA, Peres C (2001) Primate conservation in the new millennium: the role of scientists. Evol Anthropol 10: 16-33

Chapman CA, Gillespie TR, Goldberg TL (2005) Primates and the ecology of their infectious diseases: How will anthropogenic change affect host-parasite interactions? Evol Anthropol 14:134-144

Cheyne SM (2009) Challenges and opportunities of primate rehabilitation-gibbons as a case study. Endang Species Res 9:159-165

Cormier LA (2002) Monkey as food, monkey as child: Guajá symbolic cannibalism. In: Fuentes A, Wolfe L (eds) Primates face to face: the conservation implications of human-nonhuman primate interconnections. Cambridge University Press. Camb Stud Biol Evol Anthropol 29:63-8.

Corning S (2005) Public health and safety risks involved in the keeping and trade of primates as pets. In: IFAW (ed) Born to be wild-primates are not pets. International Fund for Animal Welfare, London, p 46-54. Available at www.ifaw.org/Publications/Program_Publications/Wildlife _Trade/Campaign_Scientific_Publications/asset_upload_ file812_49478.pdf

CORPOTUR (Corporación de Turísmo del Estado Nueva Esparta) (2009) Estadísticas turísticas del Estado Nueva Esparta. CORPOTUR. Dirección de Planificación y Desarrollo. Departamento de Estadísticas Turísticas, Porlamar

Di Bitetti MS, Janson CH (2001) Reproductive socioecology of tufted capuchins (Cebus apella nigritus) in northeastern Argentina. Int J Primatol 22:127-142
Duarte-Quiroga A, Estrada A (2003) Primates as pets in Mexico City: an assessment of the species involved, source of origin, and general aspects of treatment. Am J Primatol 61: $53-60$

Duplaix N (2001) Evaluation of the animal and plant trade in the Guayana Shield eco-region, preliminary findings. WWF. Available at www.giantotterresearch.com/articles/Guianas_Trade.pdf

Estrada A (2009) Primate conservation in South America: the human and ecological dimensions of the problem. In: Garber PA, Estrada A, Bicca-Marques JC, Heymann EW, Strier KB (eds) South American primates: comparative perspectives in the study of behavior, ecology, and conservation. Springer Press, New York, NY, p 463-505

Eudey AA (1994) Temple and pet primates in Thailand. Rev Ecol Terre Vie 49:273-280

Fragaszy D (2005) Enrichment for nonhuman primates: capuchin monkeys. NIH Publications, University of Georgia, Athens, GA

Fragaszy D, Visalberghi E, Fedigan L (2004) The complete capuchin. The biology of the genus Cebus. Cambridge University Press, Cambridge

- Fraser D (1999) Animal ethics and welfare science: bridging the two cultures. Appl Anim Behav Sci 65:171-189

Fuentes A (2006) Human-nonhuman primate interconnections and their relevance to anthropology. Ecol Environ Anthropol 2:1-11

García-Llorente M, Martín-López B, González JA, Alcorlo P, Montes C (2008) Social perceptions of the impacts and benefits of invasive alien species: implications for management. Biol Conserv 141:2969-2983

Hevesi R (2005) Welfare and health implications for primates kept as pets. In: Born to be wild: primates are not pets. International Fund for Animal Welfare, London, p $18-29$

Johnson-Delaney CA (1991) The pet monkey: health care and husbandry guidelines. J Small Exotic Anim Med 1:32-37

> Jones-Engel L, Engel GA, Schillact M, Froehlich JW, Paputungnan U, Kyes R (2004) Prevalence of enteric parasites among pet macaques in Sulawesi Indonesia. Am J Primatol 62:71-82

Julliot C (1996) Fruit choice by red howler monkeys (Alouatta seniculus) in a tropical rain forest. Am J Primatol 40: 261-282

> Kappeler PM, Heymann EW (1996) Nonconvergence in the evolution of primate life history and socio-ecology. Biol J Linn Soc 59:297-326

Kierulff MCM, Santos G, Canale G, Carvalho CE and others (2005) Plano de manejo para a conservação do macacoprego-do-peito-amarelo, Cebus xanthosternos. Edital FNMA/PROBIO no. 04/2001. IESB, Ilheus

> Lamb BL, Cline K (2003) Public knowledge and perception of black-tailed prairie dogs. Hum Dimens Wildl 8:127-143

Lee PC, Priston NEC (2005) Human attitudes to primates: perceptions of pests, conflict and consequences for primate conservation. In: Patterson JD, Wallace J (eds) Primatehuman interaction and conservation. American Society of Primatologists Publications, Alberta

Lima EM, Ferrari SF (2003) Diet of a free-ranging group of squirrel monkeys (Saimiri sciureus) in eastern Brazilian Amazonia. Folia Primatol 74:150-158

Lozada RA (2008) Situación de la rehabilitación de la fauna silvestre en Venezuela. MSc thesis, Universidad Simón Bolívar, Baruta

MARNR (Ministerio del Ambiente y de los Recursos Naturales Renovables) (1994) Atlas del Estado Nueva Esparta. Gráficas Internacional, Porlamar 
Mujica E, Díaz Martin D, Sobrino MC (2003) Documento base de la campaña 'Tu casa no es su casa'. Vitalis, Caracas. Available at www.vitalis.net/Tu \%20casa $\% 20 \mathrm{doc} \% 20$ base.htm

Nijman V (2005) Hanging in the balance: an assessment of trade in orang-utans and gibbons on Kalimantan, Indonesia. TRAFFIC Southeast Asia, Petaling Jaya. Available at www.traffic.org/species-reports/traffic_species_ mammals1.pdf

Nijman V (2009) An assessment of trade in gibbons and orang-utans in Sumatra, Indonesia. TRAFFIC Southeast Asia, Petaling Jaya. Available at www.indiaenvironment portal.org.in/files/Traffic\% 202009.pdf

Prescott MJ, Buchanan-Smith HM (2004) Cage sizes for tamarins in the laboratory. Anim Welf 13:151-158

Priston NEC (2005) Crop-raiding by Macaca ochreata brunnescens in Sulawesi: reality, perceptions and outcomes for conservation. $\mathrm{PhD}$ thesis, University of Cambridge

Renquist DM (1987) Zoonoses acquired from pet primates. Vet Clin North Am Small Anim Pract 17:219-240

Rodríguez JP (2007a) Editorial: extinción en Margarita. Memoria 67:3-4

Rodríguez JP (2007b) Dos décadas de innovación en conservación. Interciencia 32:293-295

Rodríguez JP, Rojas-Suárez F (1999) Libro rojo de la fauna venezolana, 2nd edn. Provita, Caracas

Rodríguez JP, Rojas-Suárez F (2008) Libro rojo de la fauna venezolana, 3rd edn. Provita, Caracas

Rowe N (1996) The pictorial guide to the living primates. Pagonias Press, New York, NY

Editorial responsibility: Anna Nekaris,

Oxford, UK
Sanz V (2007) ¿ ¿Son las áreas protegidas de la Isla de Margarita suficientes para mantener su biodiversidad? Análisis espacial del estado de conservación de sus vertebrados amenazados. Memoria 67:111-130

Sanz V, Grajal A (1998) Successful reintroduction of captiveraised yellow-shouldered Amazon parrots on Margarita Island, Venezuela. Conserv Biol 12:430-441

Sanz V, Marquez L (1994) Conservación del mono capuchino de Margarita (Cebus apella margaritae) en la Isla de Margarita, Venezuela. Neotrop Primates 2:5-8

Savage A, Guillen R, Lamilla I, Soto L (2010) Developing an effective community conservation program for cotton-top tamarins (Saguinus oedipus) in Colombia. Am J Primatol 72:379-390

Schuppli CA, Fraser D (2000) A framework for assessing the suitability of different species as companion animals. Anim Welf 9:359-372

Soulsbury CD, Iossa G, Kennell S, Harris S (2009) The welfare and suitability of primates kept as pets. J Appl Anim Welf Sci 12:1-20

Terborgh J, van Schaik CP (1987) Convergence vs. nonconvergence in primate communities. In: Gee JHR, Giller PS (eds) Organization of communities, past and present. Blackwell Scientific Publications, Oxford, p 205-226

> Wilson C, Tisdell C (2005) What role does knowledge of wildlife play in providing support for species' conservation? J Soc Sci 1:47-51

Wright J (2005) The primate trade in Indonesia: a rural perspective. BSc thesis, University of Manchester

Submitted: December 10, 2009; Accepted: November 4, 2010 Proofs received from author(s): December 15, 2010 